\title{
Perancangan Media Promosi pada Smile Island Digital Printing Menggunakan Website
}

\author{
Rina Dewi Indahsari ${ }^{1}$, Adit Sugiarto ${ }^{2}$ \\ ${ }^{1,2}$ Teknik Informatika , STMIK ASIA Malang \\ ${ }^{1}$ rinadewi@asia. ac.id, ${ }^{2}$ paydee69@gmail.com
}

\begin{abstract}
ABSTRAK
Smile Island Digital Printing adalah sebuah perusahaan yang bergerak di bidang digital printing dengan memberikan solusi dan konsultasi mengenai beragam hal mengenai dunia digital printing baik supplies, services, machine maupun output printing. Salah satu permasalahan yang dihadapi oleh Smile Island Digital Printing ini adalah sistem promosinya yang kurang maksimal sehingga menyebabkan sarana promosi tidak efektif, karena pesan yang disampaikan tidak sepenuhnya diterima dan diresapi oleh masyarakat umum. Selain itu, dengan sistem promosi yang kurang efektif tersebut memberi dampak kurangnya pesanan/ order bagi perusahaan tersebut. Untuk itu penulis mencoba membuat dan merancang aplikasi website sebagai sarana informasi dan promosi pada Smile Island Digital Printing dengan menggunakan Macromedia Dreamweaver 8, pemrograman HTML, serta CSS sebagai solusi dari permasalahan Smile Island Digital Printing. Aplikasi ini diharapkan dapat menanamkan citra baik dalam benak masyarakat, memberikan pelayanan dan kemudahan pada konsumen untuk melihat produk-produk kapanpun, dimanapun tanpa harus langsung datang ke Smile Island Digital Printing.
\end{abstract}

Kata Kunci: Promosi, Website, Sarana Informasi,

\begin{abstract}
Smile Island Digital Printing is a company engaged in the field of digital printing by providing solutions and consulting on various matters concerning both the world of digital printing supplies, services, machines and printing output. One of the problems faced by Smile Island Digital Printing is the promotion system that is less than the maximum thus causing no effective means of promotion, because the message is not fully accepted and impregnated by the general public. In addition, the system is less effective promotion of the impact the lack of order / order for these companies. To the authors tried to create and design a website application as a means of information and the promotion of Smile Island Digital Printing using Macromedia Dreamweaver 8, HTML programming, CSS as well as the solution of the problems Smile Island Digital Printing. This application is expected to instill a good image in the minds of the community, providing service and convenience to the consumer to see the products anytime, anywhere without having to directly come to Smile Island Digital Printing.
\end{abstract}

Keyword: Promotion, Website, Information Facility

\section{PENDAHULUAN}

Perkembangan dunia komputer yang begitu cepat dan semakin canggih telah membawa dampak kemajuan terutama dalam dunia desain grafis. Kebutuhan akan produkproduk dalam dunia desain grafis-pun meningkat. Setiap digital printing berlomba-lomba untuk menawarkan produk-produk terbarunya. Smile Island Digital Printing menyadari bahwa teknologi zaman sekarang ini telah berkembang dengan pesat, serta kehidupan para pelaku bisnis yang semakin sibuk telah menuntut banyak orang untuk lebih bekerja keras serta menghargai waktu. Melalui internet, masyarakat dapat dengan mudah mencari kebutuhannya. Salah satunya adalah produk-produk dan daftar harga dari berbagai website digital printing. Untuk itu Smile Island Digital Printing tertarik untuk mengkomunikasikan atau mempromosikan produknya melalui layanan internet.

Dengan perancangan website sebagai media promosi ini diharapkan dapat meningkatkan popularitas Smile Island Digital Printing. Sehingga akan meningkatkan pendapatan perusahaan serta meningkatkan pelayanan kepada pelanggan. Promosi melalui 
media internet memiliki nilai efisiensi yang cukup tinggi karena tidak membutuhkan biaya yang besar.

\section{PEMBAHASAN}

Pada dasarnya website adalah sebuah cara untuk menampilkan diri di internet, siapa saja berhak mengunjungi suatu situs yang ada di internet, baik itu untuk mengetahui informasi yang bersifat personal maupun universal. Melalui internet perusahaan juga dapat memperkenalkan dirinya sehingga dapat diketahui oleh banyak orang. Internet bagaikan sebuah pusat perdagangan terbesar di dunia dan website adalah dalam satu toko, kios, kantor di pusat perdagangan tersebut (Hendrawan, 2006).

Media promosi adalah sarana yang digunakan untuk mengkomunikasikan suatu produk / jasa/ image perusahaan ataupun yang lain untuk dapat dikenal masyarakat lebih luas. Dimana dengan promosi ini diharapkan seseorang bisa mengetahui, mengakui, memiliki, dan mengikatkan diri pada suatu barang / jasa / produk / image perusahaan (Helianthusonfri, 2013).

Konsep pembuatan website ini adalah sebagai media promosi dan komunikasi bagi Smile Island Digital Printing. Tugas penting bagi seorang pengembang website adalah memberikan ide dan gagasan tentang poin apa saja yang akan ditampilkan dalam sebuah halaman web guna mempromosikan produk yang dimiliki perusahaan. Dengan demikian seorang pengembang web juga perlu berkonsultasi dengan pemilik web itu sendiri agar segala sesuatu yang menjadi tujuan pemilik web dapat terpenuhi.

Media promosi dalam suatu perusahaan merupakan poin terpenting. Karena tanpa adanya promosi atau pengenalan kepada masyarakat, maka pengenalan produk dari perusahaan tersebut pun tidak akan sampai kepada market / pasar. Dalam hal ini, Smile Island Digital Printing memiliki kelemahan yaitu kurangnya media promosi. Promosi yang dilakukan oleh Smile Island Digital Printing hanyalah penyebaran brosur dan pamflet. Maka dari itu, dengan perancangan website pada Smile Island Digital Printing akan sangat membantu, selain sebagai media promosi yang efektif, efisien, dan mengena kepada market yang dituju. Yang harus diperhatikan dalam membuat website adalah antara lain, desain yang menarik, font yang sesuai, penempatan iklan yang sesuai, isi yang efektif dan efisien, dan yang paling penting adalah disesuaikan dengan kesukaan market yang dituju. Dengan adanya pembuatan website ini, maka diharapkan masyarakat semakin mengenal Smile Island Digital Island dan semakin mudah untuk mengetahui produk - produk terbaru yang dimiliki Smile Island Digital Printing hanya dengan cara mengakses website yang dimiliki Smile Island Digital Printing. terdiri dari:

Dalam perancangan sebuah website dibutuhkan konsep yang tepat, konsep tersebut

\section{Desain Menu}

Desain menu merupakan navigator pada sebuah halaman web yang berfungsi untuk memberikan rujukan pada tautan - tautan yang sudah tertera.

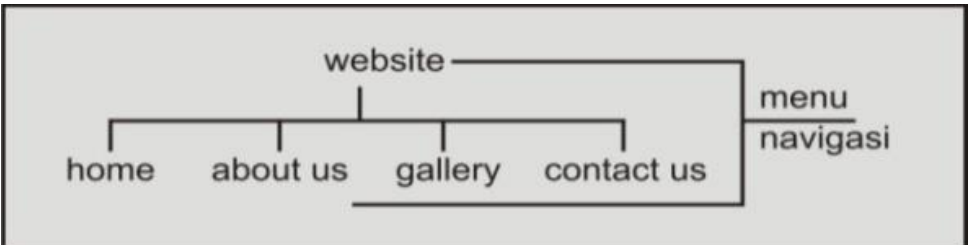

Gambar 1. Menu navigasi pada web Smile Island Digital Printing

2. Layout 
Layout atau biasa disebut story board merupakan sebuah tatanan atau komposisi dari keseluruhan halaman sebuah website yang terdiri dari Header, Logo, Menu, Frame Slide Sidebar dan Frame Bottom.

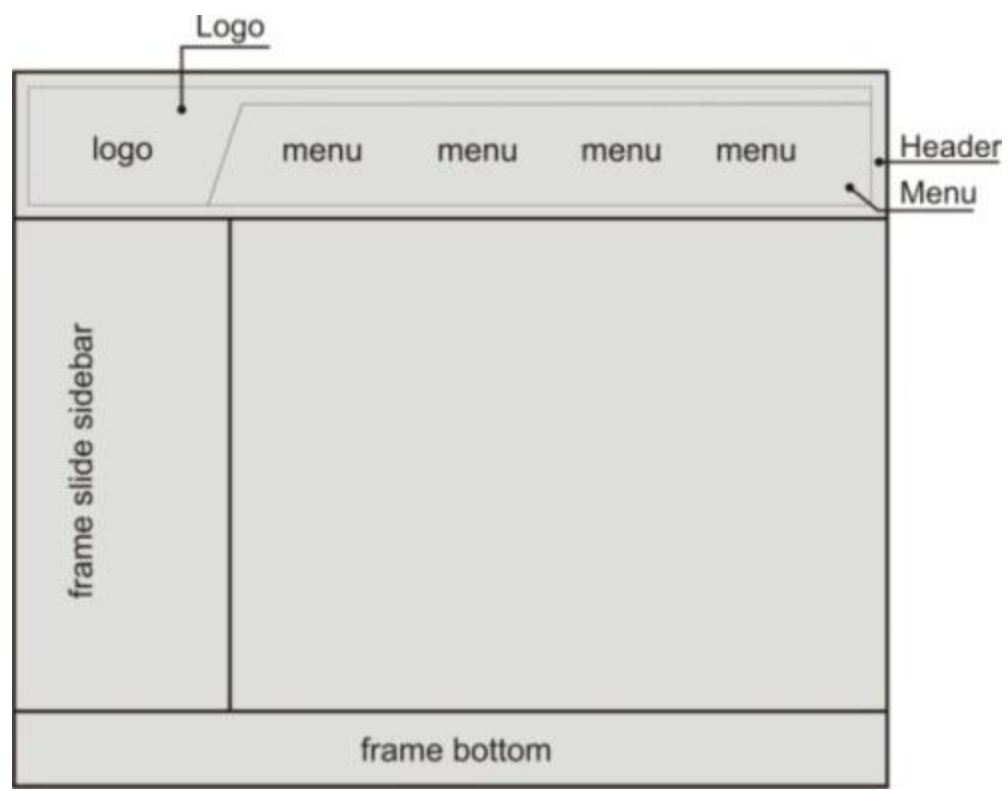

Gambar 2. Layout Web Smile Island Digital Printing

a. Header

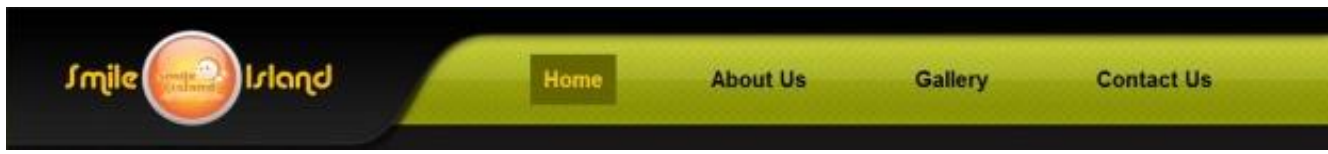

Gambar 3. Desain Header Web Smile Island Digital Printing

Header merupakan bagian dari halaman web yang pertama dilihat oleh pengguna web. Kegunaan Header adalah memberitahukan kepada pengguna web tentang apa yang sedang dikunjungi. Headerweb Smile Island Digital Printing terdiri dari logo di pojok kiri dan menubar di sisi kanan bawah. Warna dasar yang digunakan untuk logo adalah gradasi warna hitam dari gelap ke terang. Dan untuk menubar menggunakan gradasi warna hijau dari terang ke gelap.

b. Logo

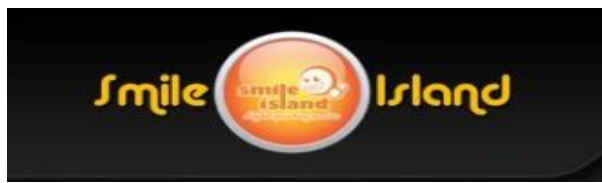

Gambar 4. Desain Logo Web Smile Island Digital Printing

Logo merupakan simbol dari sebuah perusahaan atau lainnya, dalam hal ini logo memberikan sebuah identitas pada suatu halam web. Logo yang digunakan pada web Smile Island Digital Printing ini sudah ada sebelumnya atau milik perusahaan, hanya ditambahkan tulisan Smile di sebelah kiri logo dan Island di sebelah kanan Logo. Untuk font yang digunakan pada logo adalah font alba dikarenakan memiliki kesan yang ramah 
dan simpel. Mengenai warna font, lebih condong ke warna gradasi cerah dan oranye (\#ffc000).

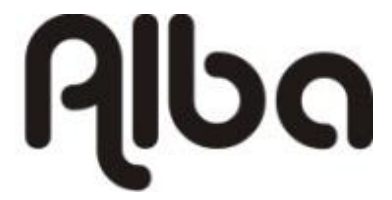

Gambar 5. Gambar Font Alba

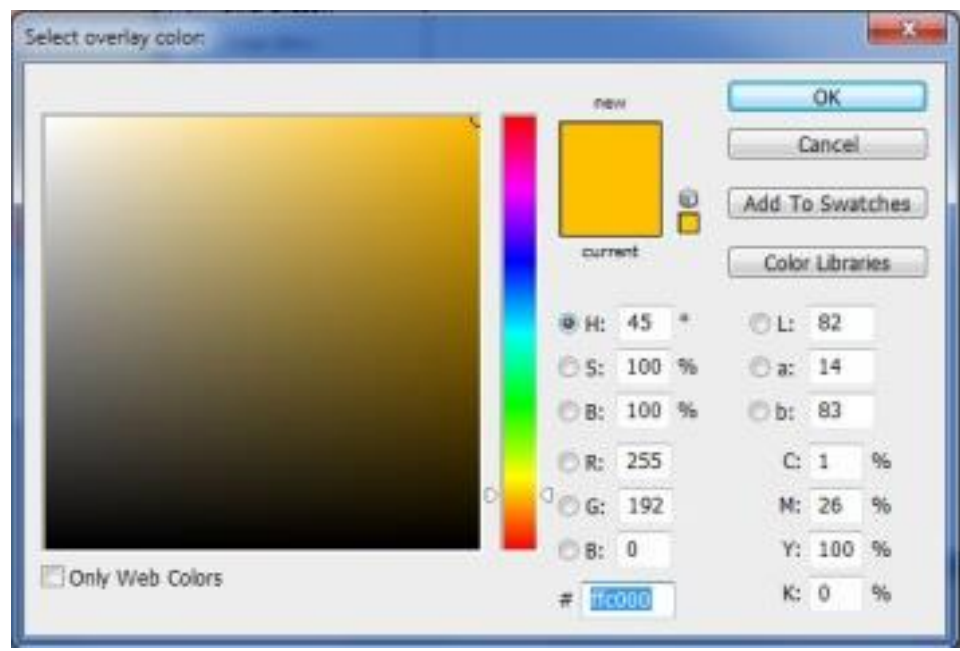

Gambar 6. Gambar Warna Font Alba

c. Menu

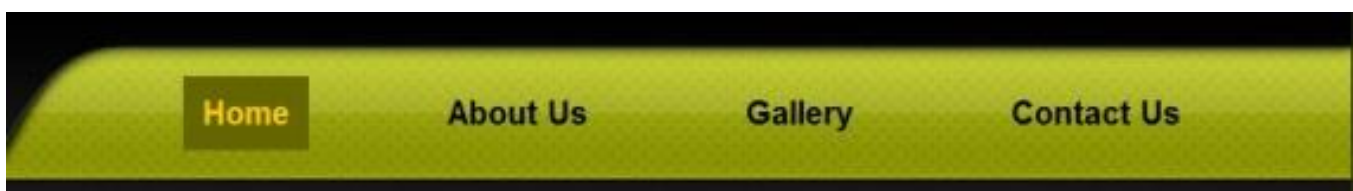

Gambar 7. Desain Menu Web Smile Island Digital Printing

Menu merupakan navigator pada sebuah halaman web yang berfungsi untuk memberikan rujukan pada tautan-tautan yang sudah tertera. Dalam web Smile Island Digital Printing ini terdapat 4 link tombol informasi yang terdiri dari tombol menu Home, About Us, Gallery dan Contact Us. Di setiap tombol menu tersebut memuat informasi yang berbeda. Desain Menu ini dibuat dengan bentuk sederhana dengan warna dasar frame gradasi hijau dari terang ke gelap dan fariasi titik-titik warna abu-abu untuk memberi kesan elegan. Dan untuk tombolnya sendiri berbentuk kotak dengan warna hijau tua dan akan muncul saat dilakukan hover.

\section{d. Sidebar}

Sidebar adalah sebuah rujukan yang pada intinya seperti link-link kategori mengenai contoh produk baik secara tertulis maupun dalam bentuk gambar, berita terbaru dan juga link untuk jejaring sosial. Pada desain ini diletakkan pada sebelah kiri halaman web. Dalam web Smile Island Digital Printing ini terdapat 3 menu pada bagian sidebar, antara lain Categories, Terkini dan Become a Fans. 


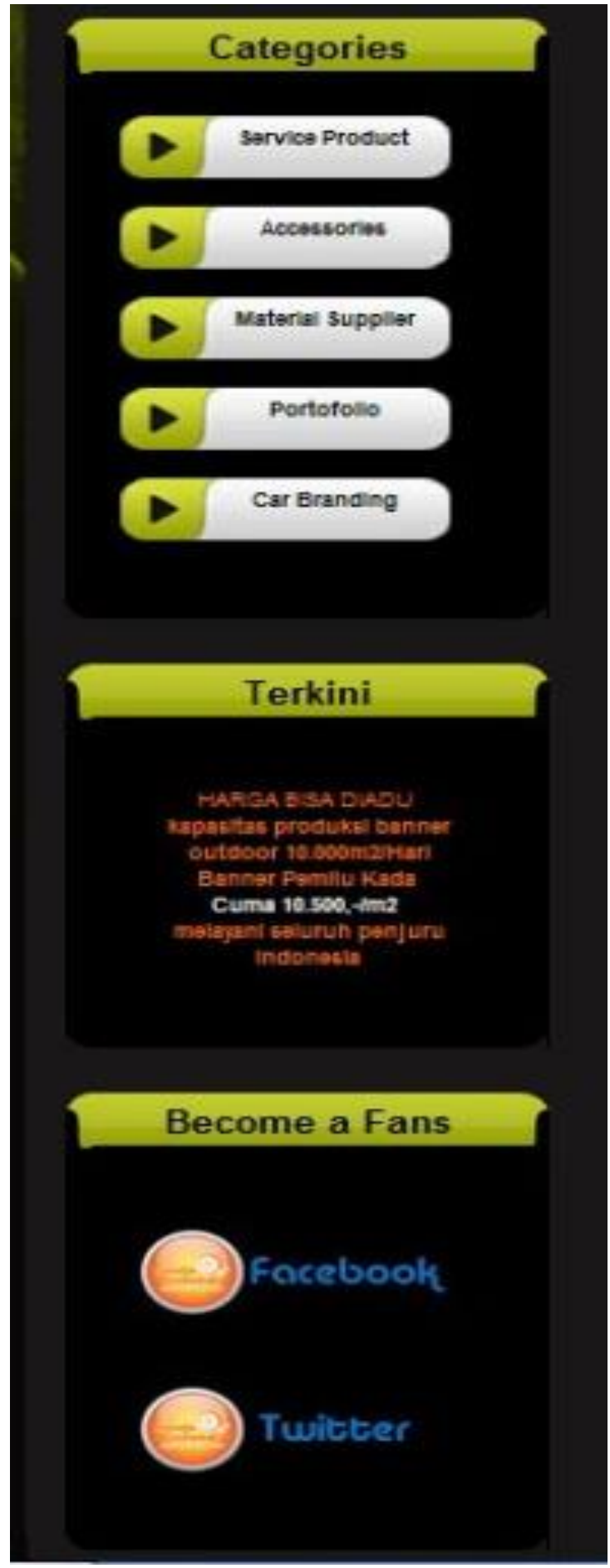

Gambar 8. Tampilan Sidebar

Sub menu Categories berisi 5 link informasi yaitu, Service Product, Accessories, Material Supplier, Portofolio dan Car Branding.

Link Service Product berisikan tentang produk-produk yang ada di Smile Island Digital Printing. Link Accessories berisi contoh produk aksesori. Link Material Supplier berisi contoh produk material. Link Portofolio berisi contoh desain yang pernah dibuat oleh Smile Island Digital Printing. Dan Link Car Branding berisi contoh produk cutting stiker yang ditempel pada mobil. 
Menu Terkini berisikan tentang informasi terbaru dari Smile Island Digital Printing baik berupa promosi maupun informasi lainnya, sedangkan Menu Become a Fans berisi link ke jejaring sosial Facebook dan Twitter yang juga berfungsi untuk memberikan penilain bagi Smile Island Digital Printing baik dari segi produk maupun pelayanannya.

Warna dasar yang digunakan untuk sidebar adalah warna hitam untuk frame, dan gradasi hijau dari terang ke gelap untuk nama menu. Sedangkan untuk tombol submenu pada Categories menggunakan perpaduan kotak dengan sudut lengkung untuk memberikan kesan elegan dan luwes. Untuk font yang digunakan pada link facebook dan twitter adalah font alba dikarenakan memiliki kesan yang ramah dan simpel. Untuk warna font, lebih condong ke warna gradasi gelap dan biru (\#0c74c4) yang sesuai dengan tema jejaring sosial tersebut.

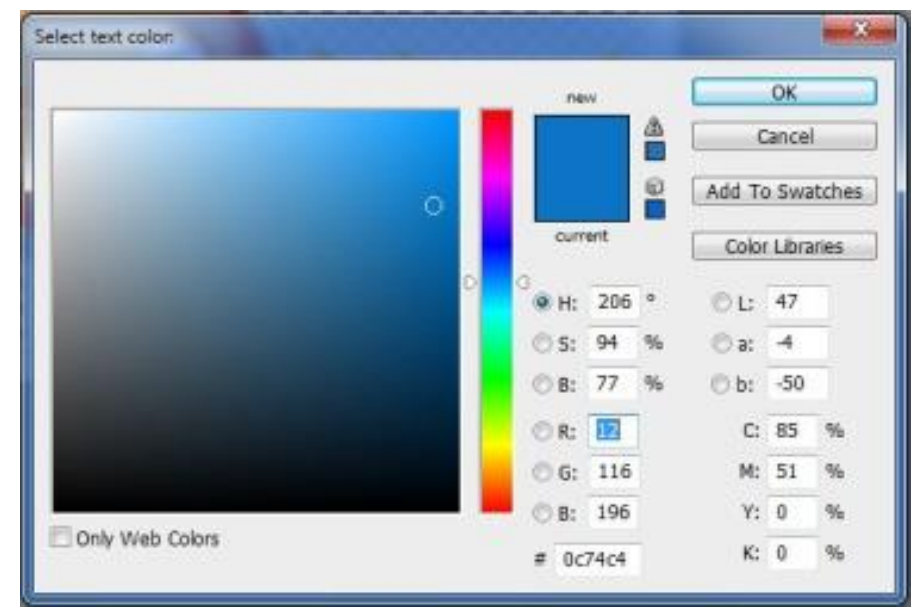

Gambar 9. Warna Font Alba pada link Facebook dan Twiter

e. Footer

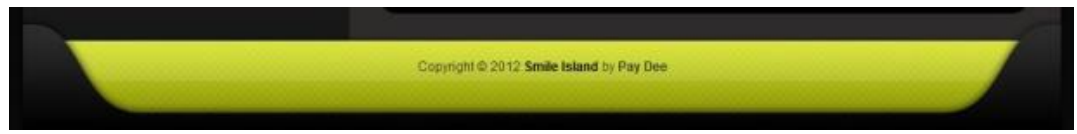

Gambar 10. Desain Footer Web Smile Island Digital Printing

Footer berfungsi untuk menunjukkan pengembang web tersebut, seorang web desainer bisa juga memberikan footer dan juga tidak, itu semua juga tergantung dari pengembangnya dengan berbagai konsep yang sudah diterapkan.

Warna dasar yang digunakan pada footer ini adalah gradasi hijau dari terang ke gelap. Dan diapit oleh lis dengan warna dasar gradasi hitam dari terang ke gelap dengan sudut-sudut lengkung untuk memberikan kesan elegan dan luwes.

Pesan yang akan ditujukan secara garis besar dalam desain meliputi kriteria sebagai berikut:

- Gaya bahasa yang digunakan yaitu gaya bahasa yang biasa digunakan dalam dunia digital printing

- Tema yang diambil adalah yang berhubungan dengan digital printing modern.

- Tipografi atau jenis huruf (font) yang dipakai sesuai dengan pengguna dan simpel sehingga mudah untuk dibaca. 
3. Implementasi

Implementasinya terdiri dari:

a. Halaman Home

Content halaman awal web Smile Island Digital Printing ini berisikan tentang pengenalan Smile Island Digital Printing sebagai pusat digital printing terlengkap dan termurah di Surabaya serta promosi produk terbaru.

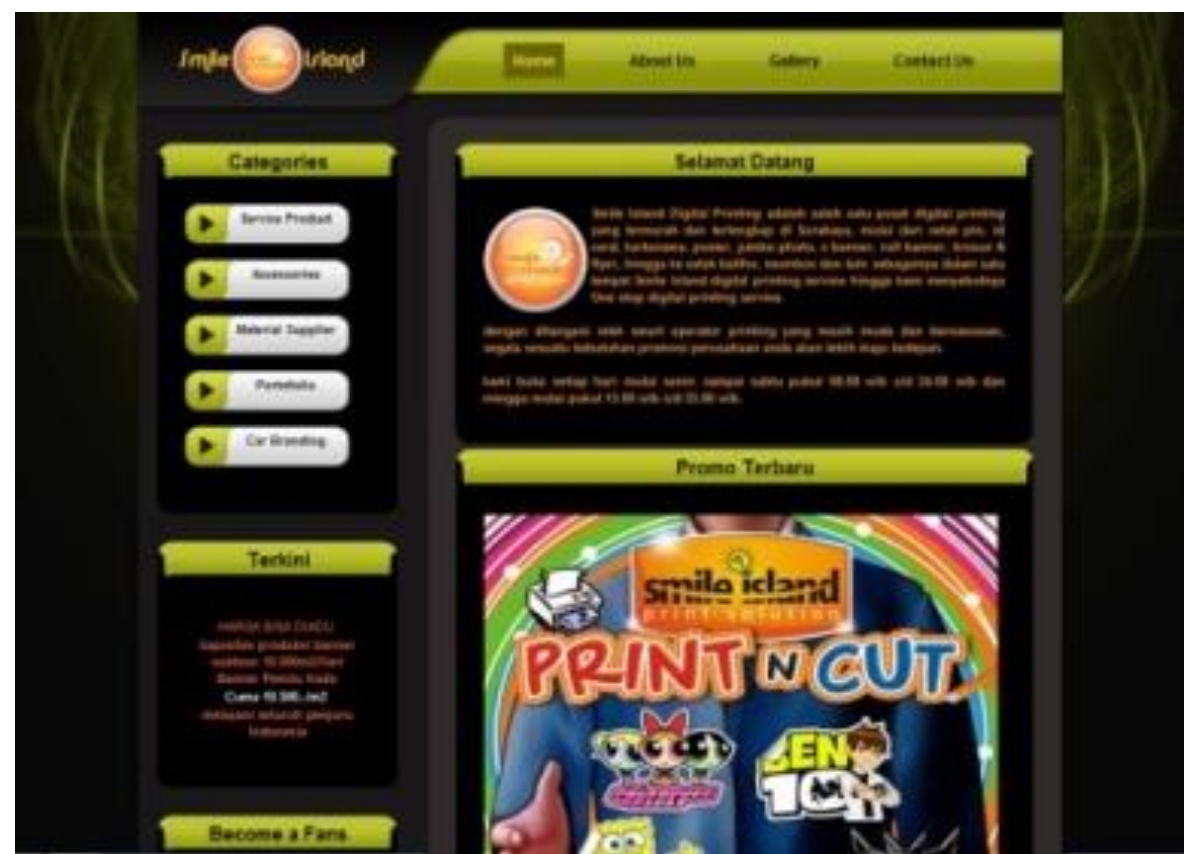

Gambar 11. Tampilan Home Smile Island Digital Printing

b. Halaman About Us

Content halaman About Us Smile Island Digital Printing ini berisikan tentang data diri, visi dan misi dari Smile Island Digital Printing.

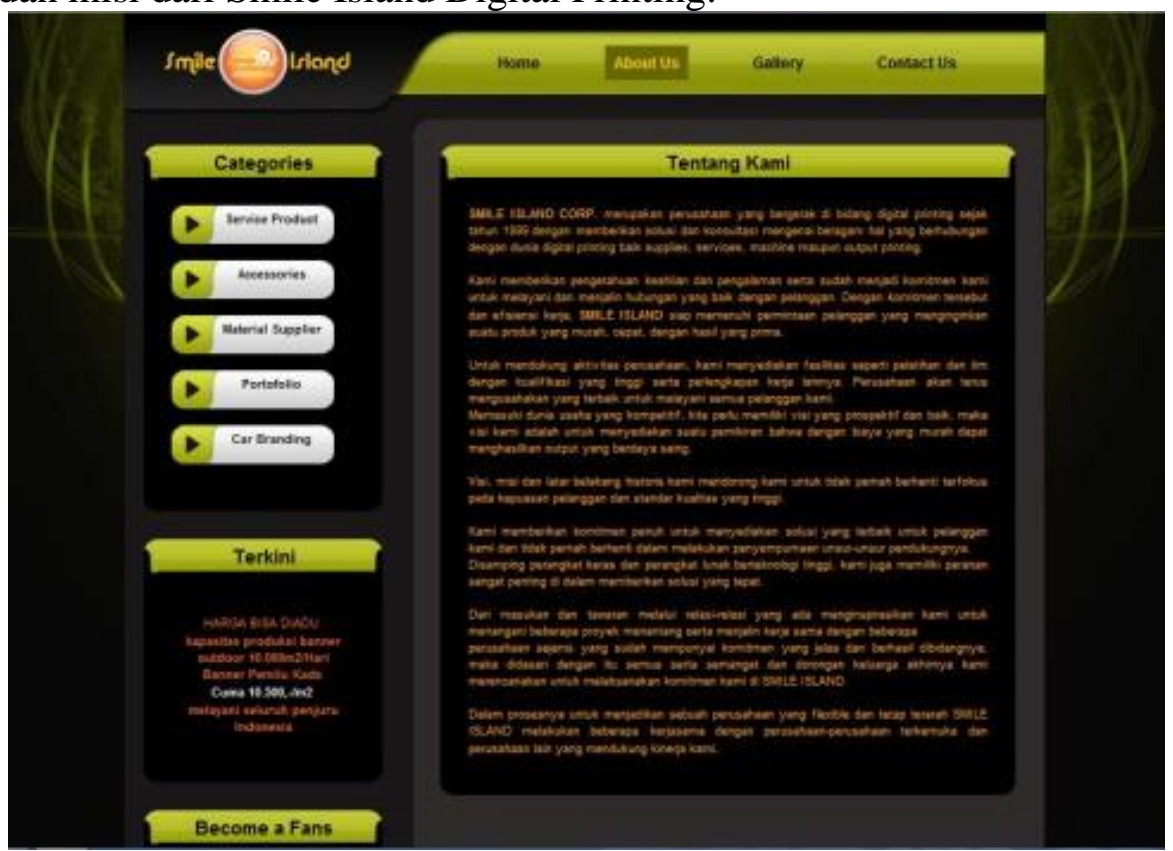

Gambar 12. Tampilan About Us Smile Island Digital Printing. 
c. Halaman Gallery

Content halaman Gallery web Smile Island Digital Printing ini berisikan tentang foto-foto dari kegiatan yang ada pada Smile Island Digital Printing mulai dari pagi hingga malam.

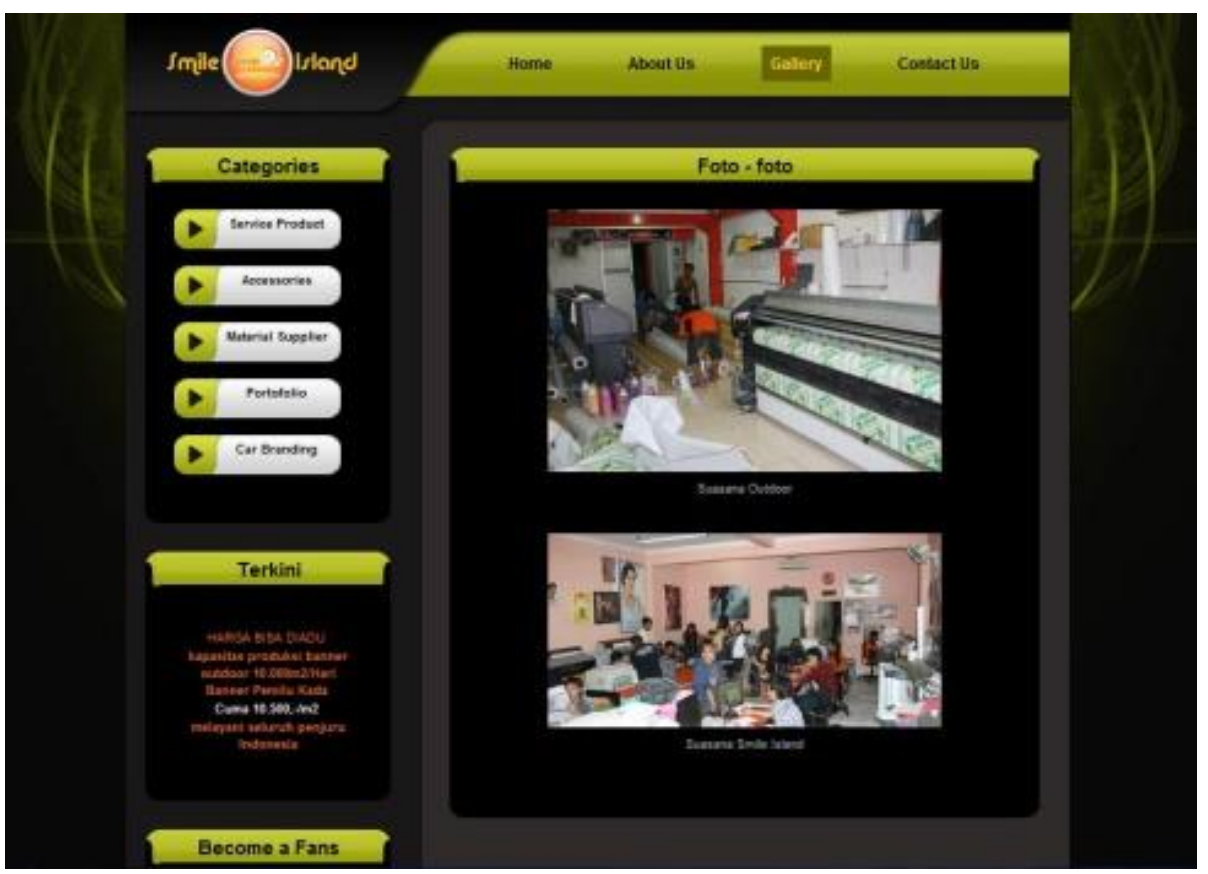

Gambar 13. Tampilan Gallery Smile Island Digital Printing

d. Halaman Contact Us

Content halaman locationweb Smile Island Digital Printing ini berisikan tentang alamat, nomor telepon dan fax serta lokasi dari Smile Island Digital Printing yang berupa sebuah peta.

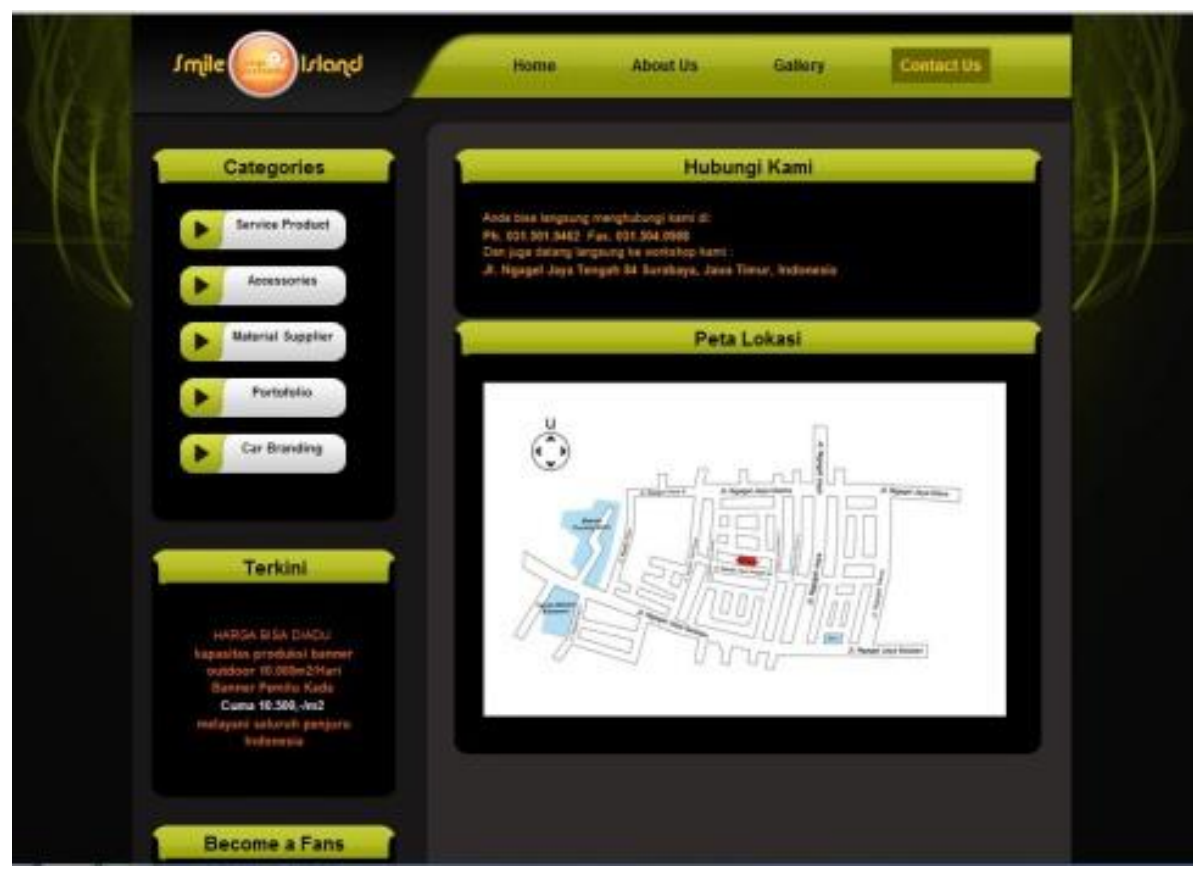

Gambar 14. Tampilan Contact Us Smile Island Digital Printing 


\section{KESIMPULAN}

Dengan website ini maka media promosi Smile Island Digital Printing bertambah satu, yang awalnya hanya berupa brosur dan pamflet. Selain itu, website ini dapat memberikan manfaat bagi Smile Island Digital Printing berupa pengenalan yang lebih luas pada masyarakat mengenai Smile Island Digital Printing sehingga dapat meningkatkan pemasukan bagi perusahaan.

\section{DAFTAR PUSTAKA}

Helianthusonfri, Jefferly. 2013. Buku Pintar Promosi di Internet. Jakarta: Elex Media Komputindo.

Hendrawan. 2013. Pengertian Website. http://www.Hendrawan.com, diunduh tanggal 4 April 2017

Jogianto. Nirmana. 1990. Elemen-Elemen Seni Dan Desain. Jakarta: Jalasutra.

Kadir, Abdul. 2003. Web Desain: Metode Aplikasi Dan Implementasi. Jakarta: Graha Ilmu.

Kristanto, Andi. 2003. Pengenalan Teori Warna. Yogyakarta: Andi. 